\title{
Cooperative, cross-boundary management facilitates large-scale ecosystem restoration efforts
}

by Erin Kelly and Jonathan Kusel

\begin{abstract}
In California and across the United States, landscape restoration projects often require cross-boundary cooperation, though successful examples are rare and not well understood. This case study describes the Burney Gardens timber harvesting plan, a cooperative, cross-boundary meadow restoration project undertaken by private corporate forest landowners in Northern California as part of a larger collaborative restoration effort. The project is notable because it (1) received institutional support - both financial and political - from federal, regional and local sources and (2) engaged a diverse group of stakeholders in pre-project planning with multiple agency partners. This approach enabled the project plan to pass through the rigorous California regulatory system in an unusually rapid fashion despite its complexity. The collaborative model of the Burney Gardens project is relevant to other restoration efforts, particularly as diverse ownerships across the West implement large-scale projects that cross property boundaries, including those of federal and private lands.
\end{abstract}

I ncreasingly, large-scale restoration projects have become a priority for land managers in the United States, leading them to look beyond reserved lands (e.g., national parks) to the mix of private and public lands that characterize many watersheds (Lindenmayer and Franklin 2002). Policies at the state and federal levels have begun to address cross-boundary management

Online: http://californiaagriculture.ucanr.edu/ landingpage.cfm?article=ca.v069n01p50\&fulltext=yes doi: 10.3733/ca.v069n01p50
— management that occurs across lands owned by different entities, with treatments implemented regardless of ownership type - facilitating both grassroots-based cooperative institutions, such as watershed councils (Rickenbach et al. 2011), and policies aimed directly at federal land managers, such as the 2009 U.S. Forest Service Collaborative Forest Landscape Restoration (CFLR) Program. U.S. Department of Agriculture Secretary Tom Vilsack stated that the U.S. Forest Service must work on restoration across property boundaries in an "all-lands approach" (USDA 2009), pointing toward the importance of land management that transcends ownership boundaries. Examples of successful cross-boundary restoration projects, however, are limited because of disparate environmental policies, economic motivations and resource (financial, technological, etc.) capacities of different ownerships (Charnley 2006).

The Burney Gardens timber harvesting plan (THP) is a cross-boundary, cooperative restoration plan developed by four private forest landowners in Northern California (Shasta County) that are part of a CFLR group. The THP was developed to restore a degraded meadow system being encroached by lodgepole pine (Pinus contorta), now growing in overstocked conditions as a result of fire suppression. Watercourses within the THP are degraded due to channelization and loss of riparian vegetation; this has resulted in erosion and insufficient shade. The Burney Gardens THP is now one of the largest watershed and meadow restoration projects ever proposed in California; restoration treatments include removal of lodgepole pine from the meadow as well as channel restoration. Some treatments have begun, such as thinning treatments around edges of the meadow, though much work remains (hydrological treatments are expected to begin summer 2015).

The Burney Gardens THP is notable for multiple reasons: it engaged government

The Burney Gardens timber harvesting plan, which covers over 2,500 acres of land held by four different owners, is one of the largest watershed and meadow restoration projects proposed in California. 
agencies and other stakeholders in extensive up-front planning; it received the support of a variety of organizations; it fostered trust and shared norms among a diverse group of stakeholders; and it enabled the CFLR group to provide evidence of a successful project, which was necessary to fulfill CFLR program mandates and leverage further funding. Furthermore, the plan was approved by regulatory agencies in less than a month, a remarkable achievement for a timber plan in California, where such plans may take over 6 months from submission to approval. The THP and associated restoration work could have generated conflict among agency review team members and the general public; its success in fostering cross-boundary cooperation and winning rapid approval make it a model worth understanding.

\section{Reasons for restoration}

Forest ownership in the United States is multifaceted, with widely varying management motivations, financial considerations, governance structures and regulatory standards. In the United States, $56 \%$ of forestland is privately owned, and $44 \%$ is publicly owned. In California, like much of the West, public ownership is higher (table 1), totaling roughly $60 \%$. The remaining $40 \%$ of forestland is private, with $14 \%$ owned by corporate (industrial and investor) entities, and $26 \%$ owned by noncorporate entities, or "family" forest owners. If coordinated restoration projects are to be successful, we must understand the conditions that encourage private landowners to work across property boundaries. This case study focuses on private corporate landowners, a group largely overlooked in previous studies on cross-boundary collaboration.

A number of studies suggest that private landowners are willing to work cooperatively for various restoration objectives (Creighton et al. 2002; Ferranto et al. 2013; Fischer and Charnley 2012; Jacobson 2002; Rickenbach et al. 2011). Most of these studies focus on hypothetical scenarios, asking landowners whether they would work across property boundaries rather than how they can create and implement projects that span ownerships. Importantly, most studies have focused on noncorporate forest owners, whose management motivations are widely recognized as multifaceted (e.g., Butler and Leatherberry 2004; Creighton et al. 2002).

Corporate landowners' motivations are less well studied and typically described in terms of economic optimization and return on investment (e.g., Wigley and Sweeney 1993), which suggests that corporate landowners have little interest in cross-boundary restoration projects. In one of the few studies to present an alternative perspective, Brody et al. (2006) surveyed representatives of 38 forest companies and found a variety of reasons agencies, including the Department of Forestry and Fire Protection (Cal Fire), regional water quality control boards and the California Department of Fish and Wildlife. In a majority of cases, a preharvest inspection is required, wherein the multi-agency review team assesses a plan in the field. Questions are directed to the forester, who is obligated to "satisfactorily" respond to these questions prior to Cal Fire's approval of the plan. A THP is often subjected to several rounds of reviews, each typically requiring modifications.

\section{Burney Gardens THP was approved in a less than a month, a remarkable achievement for a timber plan in California, where such plans may take over 6 months from submission to approval.}

for participating in restoration projects, including building relationships and trust with outside stakeholders, avoiding litigation and increasing personal satisfaction for managers.

\section{Private forest planning in California}

THPs are the key environmental documents through which forest managers secure approval for private timberland management in California; Burney Gardens project collaboration took place largely through this permitting mechanism. The plans are developed according to the California Forest Practice Rules, which regulate forestry in the state through one of the most rigorous private forest regulatory frameworks in the world (McDermott et al. 2007). THPs are written by foresters certified by the state of California and provide an opportunity for public input on private forest management projects.

As part of the approval process, THPs are reviewed by multiple state
The Burney Gardens project was the first THP to take advantage of a 2012 change in the Forest Practice Rules called the Aspen, Meadow, and Wet Area Restoration rule modification (Aspen and Meadow Rule). This rule was implemented in part because landowners and stakeholders from the Burney Gardens region identified regulatory hurdles to meadow restoration projects. The new rule was developed in recognition of changes to natural disturbance processes, particularly fire suppression, that resulted in conifer encroachment in meadows, such as those in the southern Cascade region of Burney Gardens. These meadows provide vital habitat and maintain hydrologic processes and water quality, and approximately $40 \%$ of all meadows in the region are located on privately owned lands and under the purview of the California Forest Practice Rules (Gross and Coppoletta 2013).

Under the new Aspen and Meadow Rule, managers were allowed to bypass

\begin{tabular}{|c|c|c|c|c|}
\hline \multirow[b]{2}{*}{ Region } & All forest lands & $\begin{array}{l}\text { Total public* } \\
\text { (\% of total) }\end{array}$ & $\begin{array}{l}\text { Private corporate } \\
\text { (\% of total) }\end{array}$ & $\begin{array}{c}\text { Private } \\
\text { noncorporate } \\
\text { (\% of total) }\end{array}$ \\
\hline & \multicolumn{4}{|c|}{ 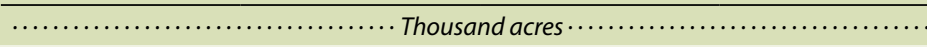 } \\
\hline Burney-Hat area & 369 & $230(62 \%)$ & $112(30 \%)$ & $26(7 \%)$ \\
\hline California & 32,817 & $19,614(60 \%)$ & $4,603(14 \%)$ & $8,600(26 \%)$ \\
\hline US total & 751,228 & $328,199(44 \%)$ & $138,120(18 \%)$ & $284,908(38 \%)$ \\
\hline
\end{tabular}

* Public lands include federal, state, and county and municipal lands.

Data from Smith et al. 2009 and USFS 2011. 
Participants from the Burney-Hat Group indicated that previous restoration efforts, especially on public lands, were not fruitful and caused frustration for neighboring landowners and stakeholders. A participating forester stated, "Rather than just sit there and plan, talk to ourselves, we needed something tangible." Most interviewees indicated that the Burney Gardens THP was a model for future projects. According to one representative of an environmental nonprofit, "We want it to be a good example of what a restoration project should look like." As likelihood of project success increased, the project grew from a few hundred acres to its final size of over 2,500 acres.

In addition to the catalytic RAC funding, Burney Gardens THP development received support from state agencies including Department of Conservation and Sierra Nevada Conservancy; federal agencies including Natural Resource Conservation Service and U.S. Fish and Wildlife Service; and the private lands manager and utility company Pacific Gas and Electric. The THP cost about $\$ 90,000$ to prepare, which included biological and archaeological assessments and document preparation, along with hydrologic restoration planning and permitting.

The Burney-Hat Group used the Burney Gardens THP to demonstrate that it could work across ownership boundaries. In 2011, the Burney-Hat Group won the Region 5, U.S. Forest Service Regional Forester's Award for All Lands Management. In early 2012, the Forest Service designated the Burney-Hat Group

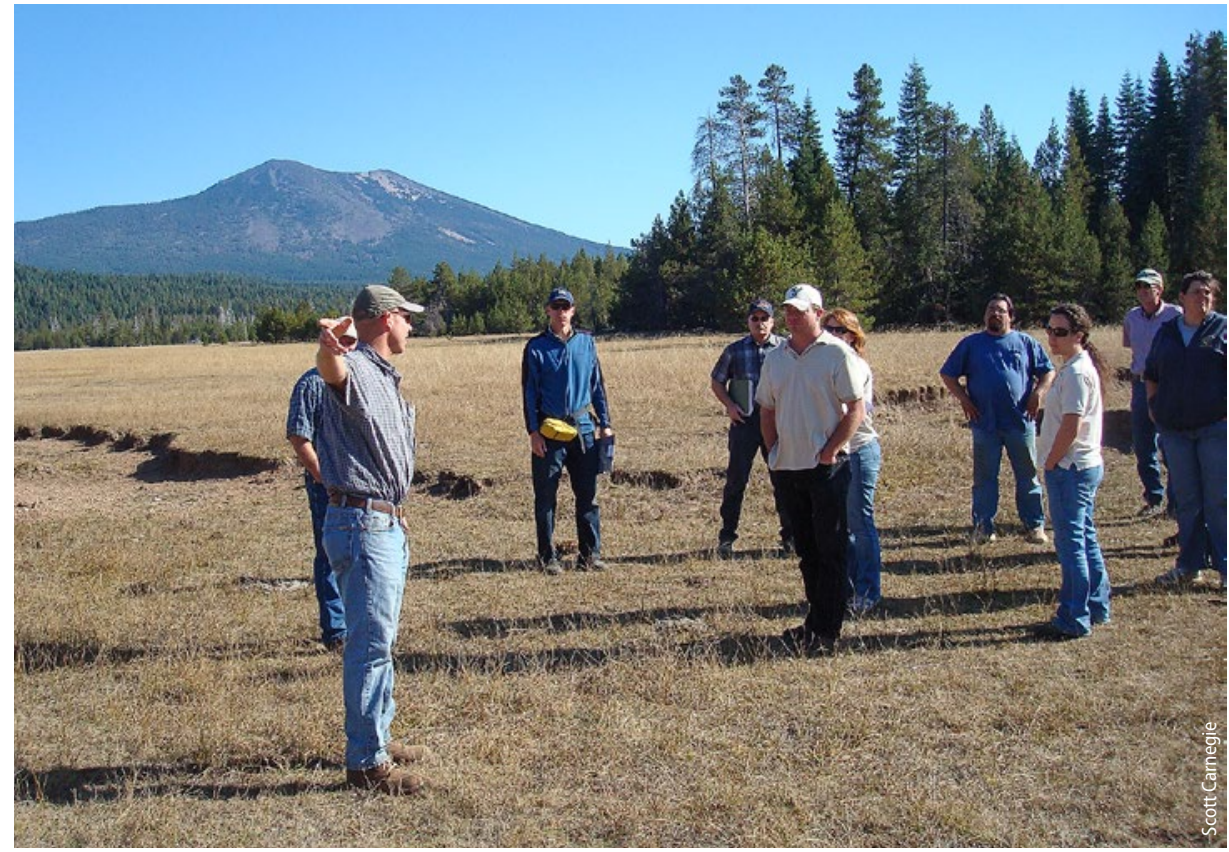

Members of the Burney-Hat group organized field trips and discussions with government agencies to inform development of the THP. The direct meetings and informal relationships that developed over time contributed to trust and, ultimately, the ability of both private landowners and agency personne to effectively work together.

and the Lassen National Forest's Burney and Hat Creek landscape $(369,000$ acres total) as one of three CFLR projects in California. As part of this designation, the Burney-Hat Group received \$10 million to be spent over 10 years for landscape restoration on national forest and adjacent private lands, and for improvement of community socioeconomic health. In this manner, the Burney Gardens project leveraged support and expanded landscape restoration possibilities.

Regulatory agencies and THP process review. The process review for development of the THP demonstrates the extent of upfront, pre-project planning that was both unusual and essential to its success (fig. 1). In contrast to the process for a typical THP, in which a forester submits a plan to Cal Fire and then receives and responds to suggestions from multiple regulatory agencies, the Burney Gardens THP grew out of a July 2011 meeting called by the Burney-Hat Group working with the central Sierra-based Amador Calaveras Consensus Group and the Sierra Nevada Conservancy. State and federal agencies were asked to participate in this meeting to discuss advancing alllands work. Burney-Hat Group members

\section{Typical THP review process}

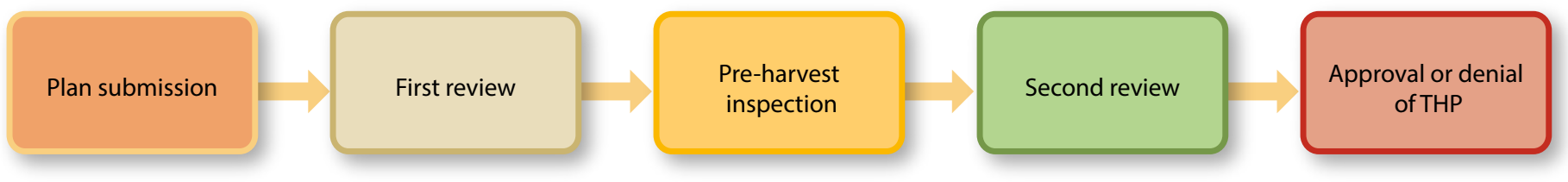

\section{Upfront THP review process}

\section{Pre-consult and field trips (joint learning) with agencies}
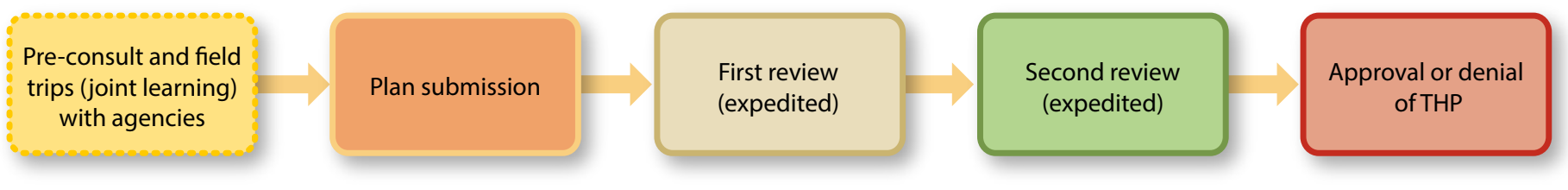

Fig. 1. The top row illustrates a typical THP review process, with multi-agency reviews of submitted plans. The second row illustrates an upfront process, with agency input into plan creation. 
contacted review agencies directly to ask whether they would engage in preconsultation discussions and organized field trips to inform development of the THP (fig. 1). With support from a Cal Fire deputy director, who had at the July meeting agreed to participate, other agencies joined the field trips and discussions. Site visits with land managers and agency staff continued through the fall of 2011.

The passage of the Aspen and Meadow Rule, coupled with support from mid- to high-level officials within the regulatory agencies, provided impetus to local agency personnel to engage with and support the Burney Gardens THP. Instead of responding to comments from agencies after the bulk of planning was completed, foresters were able to incorporate agency concerns into plan development. Moreover, the direct meetings and informal relationships developed over time contributed to trust and, ultimately, the ability of both private landowners and agency personnel to effectively work together. Although upfront work for the THP was extensive and involved more field visits than a typical THP, interviewees felt it resulted in a better plan and proved to be more efficient than the typical review process.

Local biomass capacity. For the private land managers, a shared sense of the need to manage the land base and mutual familiarity with timber management and planning made partnership work. However, the meadow restoration described in the Burney Gardens THP can only be realized if the THP is fully implemented, and as of winter 2015 there remain several barriers to completing the work, as well as future all-lands work in the Burney-Hat landscape. Approximately 113 acres of single-tree selection have occurred thus far, but none of the meadow restoration work has been completed.

The most significant barrier for Burney Gardens as of 2015 is the lack of biomass capacity in the local area. Small diameter material removed from restoration projects such as the Burney Gardens THP has limited economic value. Two active biomass facilities remain in close proximity to the project area, but only one accepts biomass from outside entities. The amount of material generated by the Burney Gardens project is expected to saturate the limited local market, depressing prices that are already low. With limited economic utility for biomass material, less restoration is possible.

\section{New policy directions}

The Burney Gardens THP demonstrates that large-scale restoration projects can be successfully developed on private lands involving multiple owners - in this case, multiple corporate-owned private forestlands. The circumstances surrounding the creation of the Burney Gardens THP point toward policy directions to facilitate cross-boundary management, in particular (1) nested, multi-scaled institutional support at the regional, state and federal levels and (2) coherent, upfront project planning.

Corporate landowner motivations. Like Brody et al. (2006), we found motivations for restoration that encompassed more than economic optimization. Clewell and Aronson (2006) described five types of landowner motivations for restoration, including technocratic, in which legal requirements mandate restoration activities; biotic, such as biodiversity protection; heuristic, in which restoration is educational; idealistic, in which humans seek to atone for degradation; and pragmatic, in which ecosystem services are valued and enhanced. Corporate landowners' restoration objectives are typically driven by economic self-interest and technocratic, or law-abiding, motivations.

The Burney Gardens project showed that corporate landowner motivations can exceed narrow self-interest. While corporate landowners participated in part to convince the Forest Service to treat its overstocked forests as part of the CFLR program - resulting in reduced risk of fire moving from federal forests to their private lands - we also found that biotic and idealistic reasons were put forth by the corporate land managers in describing the project as "the right thing to do" to achieve a healthier landscape. Pragmatic reasons, such as water quality improvements and improved grazing, were also cited as important. Even heuristic reasons were cited as motivation for the project, as the corporate land managers wanted to demonstrate the efficacy of meadow restoration and the success of the collaborative group in moving from project concept to implementation.

These findings suggest that future restoration projects involving corporate landowners may encourage participation through more than legal requirements or economic incentives. Whether because of the landowners' desire for social license and approval from neighbors or because of individual managers' sense of stewardship, motivations for participating in joint landscape management and restoration 
As a result of conifer encroachment on 1,360 acres of meadow, watercourses have little or no riparian vegetation and have been channelized (right), resulting in increased erosion and water quality degradation

are more complex than previously granted. There is need for additional exploration of the impetus behind corporate landowner behavior, especially to promote corporate landowners as partners in restoration projects within the all-lands management goals of the U.S. Forest Service.

Nested institutional support. The creation of the Burney Gardens THP was successful because of a nested series of supportive institutions at multiple levels (from regional to federal), confirming previous findings (Epanchin-Neill et al. 2010; Ostrom 2012; Rickenbach et al. 2011). Epanchin-Neill et al. (2010) proposed bottom-up, middle-level and topdown institutions, each with different roles in a cooperative partnership, with middle-level organizations facilitating communication and mediating between the managers on the ground and governmental agencies. In this case, the BurneyHat Group and the Fall River Resource Conservation District filled this middlelevel role, which was further embedded in and supported by funding from the Shasta County RAC and the federal CFLR
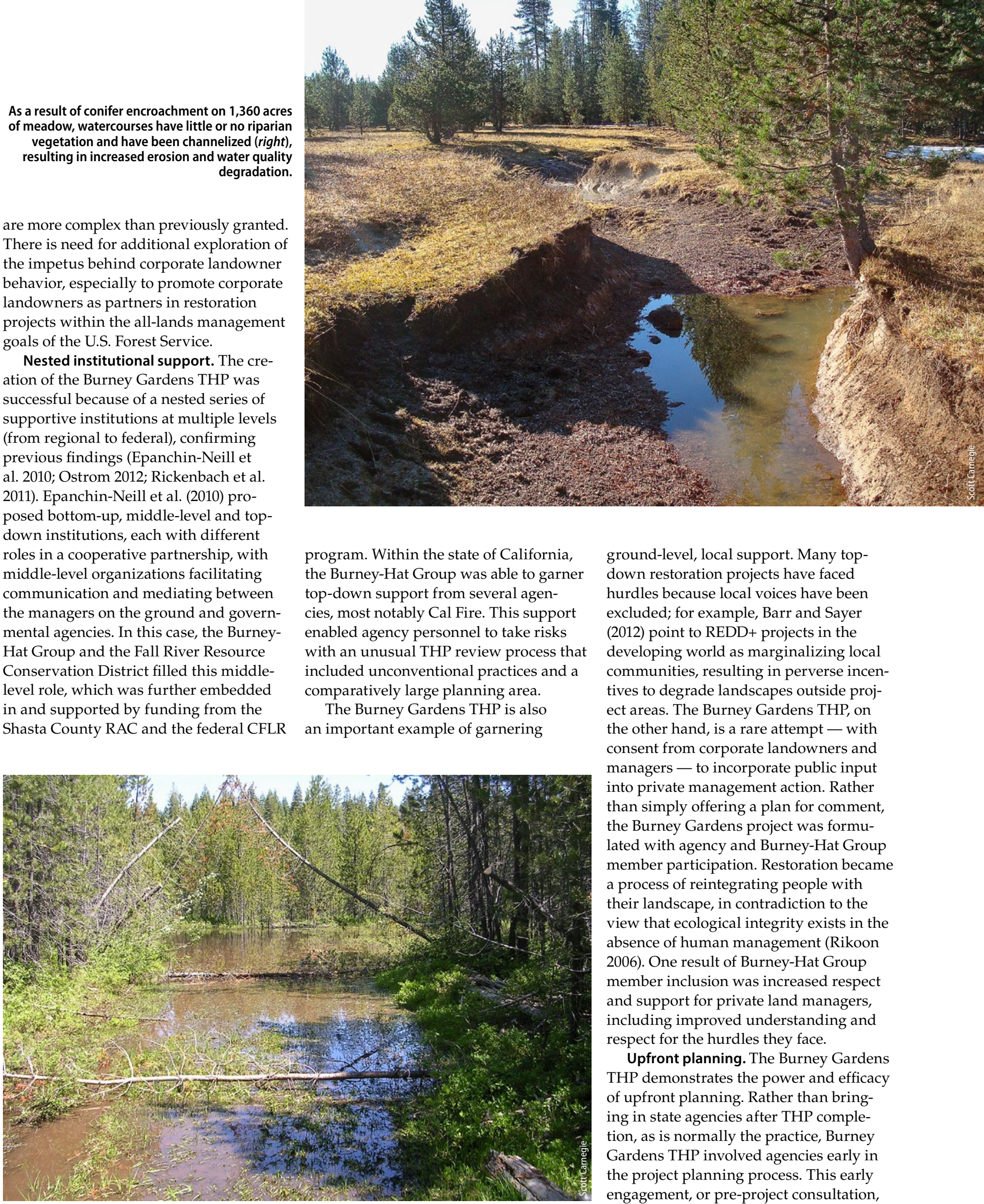

program. Within the state of California, the Burney-Hat Group was able to garner top-down support from several agencies, most notably Cal Fire. This support enabled agency personnel to take risks with an unusual THP review process that included unconventional practices and a comparatively large planning area.

The Burney Gardens THP is also an important example of garnering

Above, an example of lodgepole pine encroachment and a watercourse without hardwood riparian vegetation.

ground-level, local support. Many topdown restoration projects have faced hurdles because local voices have been excluded; for example, Barr and Sayer (2012) point to REDD+ projects in the developing world as marginalizing local communities, resulting in perverse incentives to degrade landscapes outside project areas. The Burney Gardens THP, on the other hand, is a rare attempt — with consent from corporate landowners and managers - to incorporate public input into private management action. Rather than simply offering a plan for comment, the Burney Gardens project was formulated with agency and Burney-Hat Group member participation. Restoration became a process of reintegrating people with their landscape, in contradiction to the view that ecological integrity exists in the absence of human management (Rikoon 2006). One result of Burney-Hat Group member inclusion was increased respect and support for private land managers, including improved understanding and respect for the hurdles they face.

Upfront planning. The Burney Gardens THP demonstrates the power and efficacy of upfront planning. Rather than bringing in state agencies after THP completion, as is normally the practice, Burney Gardens THP involved agencies early in the project planning process. This early engagement, or pre-project consultation, laid the groundwork for communication and openness and subsequent integration 
of agency concerns into the plan that was submitted. Project designers were able to proactively address concerns through integrative discussions among multiple landowners and agency members, rather than leaving individual foresters to respond to agency comments after plan submission. Instead of trying to advance a project that would pass inspection but produce diminished restoration results, upfront and multi-stakeholder planning enabled the Burney THP to incorporate diverse goals and tackle multiple issues. The result was a coherent, large-scale restoration project that included both commercial timber production (through single-tree selection harvests) and meadow restoration.

These findings have implications for public land managers on federal lands, whose energies are too often focused on procedural issues associated with public processes mandated by with the National Environmental Policy Act (NEPA) and potential litigation. According to Mortimer et al. (2011), this situation has resulted in delayed decision making and led to excessive risk aversion within the agency. Upfront planning for NEPA documentation is a relatively new tactic for the U.S. Forest Service, which has long presented the public with pre-digested alternatives and a preferred option developed without stakeholder involvement. With upfront planning, the Forest Service could incorporate the views of stakeholder groups into its projects, potentially leading to a less adversarial NEPA process, successful project implementation and trust building for subsequent management projects.

\section{Future research and next steps}

As the all-lands approach is extended to more multi-jurisdictional landscapes, federal land managers will need to consider ways to support and integrate private landowner participation. Private landowners join collaborative groups when the benefits outweigh the costs of meeting and negotiating outcomes (Lubell et al. 2002). In this case, transaction costs were reduced through the creation of a supportive network of organizations that provided both funding and political backing for restoration, and extensive upfront planning that allowed the landowners to create a coherent and integrative restoration strategy rather than responding piecemeal to agency concerns.
Although the Burney Gardens project grew out of a multi-jurisdictional landscape group, the project remained focused on private land. Integrating private and federal land management is a needed next step, and one that will likely prove more difficult. The summer 2014 fires that burned tens of thousands acres in the CFLR area, including private land, will challenge and compel partners to not only work through frustrations as a result of losses associated with the fires, but differences in landscape objectives and practices. Though barriers to full completion remain, the Burney Gardens project offers the outlines of success that inform how to develop a more resilient landscape and contribute to socioeconomic vitality of nearby communities. CA

\section{References}

Barr CM, Sayer JA. 2012. The political economy of reforestation and forest restoration in Asia-Pacific: Critical issues for REDD+. Biol Conserv 154:9-19.

[BOF] Board of Forestry. 2011. Notice of proposed rulemaking, Aspen, Meadow and Wet Area Restoration, published June 24, 2011. Sacramento, CA: Board of Forestry.

Brody SD, Cash SB, Dyke J, Thornton S. 2006. Motivation for the forest industry to participate in collaborative ecosystem management initiatives. Forest Policy Econ 8:123-34

Burney-Hat Creek Community Forest and Watershed Group. 2011. Burney-Hat Creek Basins Project: A Collaborative Landscape Restoration Program Proposal. www. fs.fed.us/restoration/documents/cflrp/2011Proposals/ Region5/Lassen/R5LassenNF.pdf.

Butler BJ, Leatherberry EC. 2004. America's family forest owners. J Forest 102:4-14.

Charnley S. 2006. The Northwest Forest Plan as a model for broad-scale ecosystem management: a social perspective. Conserv Biol 20:330-40.

Clewell AF, Aronson J. 2006. Motivations for the restoration of ecosystems. Conserv Biol 20:420-28.

Creighton JH, Baumgartner DM, Blatner KA. 2002. Ecosystem management and nonindustrial private forest landowners in Washington State, USA. Small-scale Forest Econ Manag Pol 1:55-69.

Epanchin-Neill RS, Hufford MB, Aslan CE, et al. 2010 Controlling invasive species in complex social landscapes. Fron Ecol Environ 8:210-16.

Ferranto S, Huntsinger L, Getz C, et al. 2013. Management without borders? A survey of landowner practice and attitudes toward cross-boundary cooperation. Society Nat Res 26:1082-1100.

Fischer AP, Charnley S. 2012. Risk and cooperation: Managing hazardous fuel in mixed ownership landscapes. Environ Manage 49:1192-1207.

Gross S, Coppoletta M. 2013. Historic Range of Variability for Meadows in the Sierra Nevada and South Cascades (draft). Vallejo, CA: US Department of Agriculture, Forest Service, Pacific Southwest Region.

Jacobson MG. 2002. Ecosystem management in the Southeast United States: Interest of forest landowners in joint management across ownerships. Small-scale Forest Econ Manag Pol 1:71-92.
E. Kelly is Assistant Professor in the Department of Forestry and Wildland Resources at Humboldt State University; J. Kusel is Executive Director, Sierra Institute for Community and Environment. The California Forest Foundation provided funding to Dr. Kelly.
Lindenmayer DB, Franklin JF. 2002. Conserving Forest Biodiversity: A Comprehensive Multiscaled Approach. Washington, DC: Island Press.

Lubell M, Schneider M, Scholz JT, Mete M. 2002. Watershed partnerships and the emergence of collective action institutions. Am J Polit Sci 46:148-63.

McDermott CL, Cashore B, Kanowski P. 2007. A global comparison of forest practice policies using Tasmania as a constant case. GISF research paper 010, Yale Program on Forest Policy and Governance.

Mortimer MJ, Stern MJ, Walmsheimer RW, et al. 2011. Environmental and social risks: Defensive National Environmental Policy Act in the US Forest Service. J Forest 109:27-33.

Ostrom E. 2012. Nested externalities and polycentric institutions: Must we want for global solutions to climate change before taking actions at other scales? Econ Theor 49:353-69.

Rickenbach M, Schulte LA, Kittredge DB, et al. 2011. Cross-boundary cooperation: A mechanism for sustaining ecosystem services from private lands. J Soil Water Conserv 66:91A-96A.

Rikoon JS. 2006. Wild horses and the political ecology of nature restoration in the Missouri Ozarks. Geoforum 37:200-11.

Smith WB, Miles PD, Perry CH, Pugh SA. 2009. Forest Resources of the United States, 2007. General Technical Report WO-78. Washington, DC: US Department of Agriculture, Forest Service. 336 p.

Strauss A, Corbin J. 1990. Basics of Qualitative Research: Grounded Theory Procedures and Techniques. Sage Publications.

Thompson RP, Dicus CA. 2005. Characterizing the regulatory environment affecting the forest products industry in California. Available: http://works.bepress. com/cdicus/6.

[USDA] US Department of Agriculture. 2009. Agriculture Secretary Vilsack presents national vision for America's forests. News transcript, release no. 0382.09. www.usda. $\mathrm{gov} / \mathrm{wps} / \mathrm{portal} / \mathrm{usda} / \mathrm{usdahome}$ ?contentidonly=true $\& \mathrm{c}$ ontentid=2009/08/0382.xml.

Wigley TB, Sweeney JM. 1993. Cooperative partnerships and the role of private landowners. In: Finch DN, Stangel PW (eds.). Status and Management of Neotropical Migratory Birds. Sept. 21-25, Estes Park, Colorado. USDA, US Forest Service General Technical Report RM-229. 